\title{
Wolbachia prevalence in the vector species Culex pipiens and Culex torrentium in a Sindbis virus-endemic region of Sweden
}

\author{
Alexander Bergman and Jenny C. Hesson* (1)
}

\begin{abstract}
Background: Wolbachia pipientis are endosymbiotic bacteria present in a large proportion of terrestrial arthropods. The species is known to sometimes affect the ability of its host to transmit vector-borne pathogens. Central Sweden is endemic for Sindbis virus (SINV), where it is mainly transmitted by the vector species Culex pipiens and Culex torrentium, with the latter established as the main vector. In this study we investigated the Wolbachia prevalence in these two vector species in a region highly endemic for SINV.

Methods: Culex mosquitoes were collected using CDC light traps baited with carbon dioxide over 9 years at 50 collection sites across the River Dalälven floodplains in central Sweden. Mosquito genus was determined morphologically, while a molecular method was used for reliable species determination. The presence of Wolbachia was determined through PCR using general primers targeting the wsp gene and sequencing of selected samples.

Results: In total, 676 Cx. pipiens and 293 Cx. torrentium were tested for Wolbachia. The prevalence of Wolbachia in CX. pipiens was $97 \%$ (95\% Cl 94.8-97.6\%), while only $0.7 \%$ (95\% Cl 0.19-2.45\%) in Cx. torrentium. The two Cx. torrentium mosquitoes that were infected with Wolbachia carried different types of the bacteria.

Conclusions: The main vector of SINV in the investigated endemic region, $C x$. torrentium, was seldom infected with Wolbachia, while it was highly prevalent in the secondary vector, Cx. pipiens. The presence of Wolbachia could potentially have an impact on the vector competence of these two species. Furthermore, the detection of Wolbachia in $C X$. torrentium could indicate horizontal transmission of the endosymbiont between arthropods of different species.
\end{abstract}

Keywords: Vector, Field, Mosquito, Endosymbiont, Alphavirus, Horizontal transmission, Scandinavia

\section{Background}

The transmission of arboviruses is influenced by a number of factors, including both abiotic (e.g., temperature) and biotic elements (e.g., vector immune status) [1-4]. One important biotic factor is the intracellular symbiont Wolbachia pipientis (Class: Alphaproteobacteria, Order: Rickettsiales), present in some nematode species and an estimated $40 \%$ of all terrestrial arthropods [5]. Wolbachia

*Correspondence: jenny.hesson@imbim.uu.se Department of Medical Biochemistry and Microbiology, Zoonosis Science Center, Uppsala University, Uppsala, Sweden is a genetically diverse species, composed of 18 phylogenetically distinct supergroups described to date (A-R) [6]. Deeply involved in the reproduction of its host [7], Wolbachia is known for inducing cytoplasmic incompatibility and giving rise to crossing types, most studied in Culex pipiens and its Wolbachia strain wPip, which belongs to supergroup B [8-10]. Additionally, it is well established that Wolbachia infection in mosquitoes can influence their ability to become infected and transmit several arboviruses [11-14].

In a global context, Culex mosquitoes are important vectors for, e.g., West Nile virus (WNV) and Japanese encephalitis virus (JEV) [15-18]. In Central and original author(s) and the source, provide a link to the Creative Commons licence, and indicate if changes were made. The images or other third party material in this article are included in the article's Creative Commons licence, unless indicated otherwise in a credit line to the material. If material is not included in the article's Creative Commons licence and your intended use is not permitted by statutory regulation or exceeds the permitted use, you will need to obtain permission directly from the copyright holder. To view a copy of this licence, visit http://creativecommons.org/licenses/by/4.0/. The Creative Commons Public Domain Dedication waiver (http://creativeco mmons.org/publicdomain/zero/1.0/) applies to the data made available in this article, unless otherwise stated in a credit line to the data. 
Northern Europe, the morphologically identical vector species $C x$. pipiens and $C x$. torrentium are enzootic vectors of both WNV and Sindbis virus (SINV), transmitting these viruses among birds [19-22]. SINV is an arthritogenic alphavirus present throughout the Old World [23], although outbreaks of human disease are only reported from South Africa [24, 25] and Fennoscandia [26-29]. In Sweden, SINV is considered endemic to the central and northern parts of the country [28-30].

Culex torrentium is regarded as the most important enzootic vector in Sweden due to its high abundance in endemic areas, high infection rate, and superior vector competence to $C x$. pipiens [31-34]. One difference between $C x$. torrentium and $C x$. pipiens is the prevalence of Wolbachia-infected individuals. Previous studies in Germany, Belgium, Russia, Belarus, Kazakhstan, and Kyrgyz Republic have found Wolbachia to be very common in Cx. pipiens but absent in Cx. torrentium [35-38]. It is therefore possible that these differences in Wolbachia infection status could account for part of the difference in vector competence seen between $C x$. pipiens and $C x$. torrentium. Previous studies have however only been performed in regions without intense SINV transmission. Therefore, this study aims at investigating the Wolbachia prevalence in $C x$. pipiens and $C x$. torrentium collected in a highly SINV-endemic region in central Sweden.

\section{Methods}

\section{Mosquitoes}

Mosquitoes were collected at 50 different locations across the River Dalälven floodplains (Fig. 1) as part of a routine mosquito monitoring programme [39]. SINV is considered endemic to this region and some of the highest infection rates in mosquitoes have been detected here $[22,33]$. Collections were performed every second week between May and September during the years 2010-2018 using CDC light traps baited with carbon dioxide. Mosquitoes were identified based on morphological characteristics [40], and $C x$. pipiens/torrentium were sorted out and used for molecular identification to species. Briefly, individual mosquitoes were homogenized in $500 \mu \mathrm{l}$ of phosphate-buffered saline (PBS) supplemented with $20 \%$ heat-inactivated fetal bovine serum, $100 \mathrm{U} / \mathrm{ml}$ penicillin, $100 \mu \mathrm{g} / \mathrm{ml}$ streptomycin, and $2.5 \mu \mathrm{g} / \mathrm{ml}$ amphotericin B (Thermo Fischer Scientific; Waltham, MA, USA) using two steel beads in the Qiagen TissueLyser $\mathrm{II}^{\mathrm{TM}}$ (Qiagen; Hilden, Germany). Five microliters ( $5 \mu \mathrm{l})$ of the homogenate was pretreated by incubating at $98{ }^{\circ} \mathrm{C}$ for $2 \mathrm{~min}$ in $20 \mu \mathrm{l}$ of dilution buffer with $0.5 \mu \mathrm{l}$ of DNA release additive, part of the Phire Tissue Direct PCR Master Mix kit (Thermo Scientific; Vilnius, Lithuania). The pretreated homogenate was stored at $-20{ }^{\circ} \mathrm{C}$ before being used as a template in polymerase chain reaction (PCR).
Conventional PCR of part of the cytochrome oxidase subunit I (COI) was performed in $20 \mu \mathrm{l}$ reactions with $1 \mu \mathrm{l}$ template using the forward primer C1-J-2183 (5'CAACATTTATTTTGATTTTTTGG-3') and the reverse primer TL2-N-3014 (5'-TCCAATGCACTAATCTGC CATATTA- $3^{\prime}$ ) at a concentration of $0.5 \mu \mathrm{M}$ each under the following thermocycler conditions: initial denaturation at $98{ }^{\circ} \mathrm{C}$ for $5 \mathrm{~min}$, followed by 40 cycles of denaturation at $98{ }^{\circ} \mathrm{C}$ for $5 \mathrm{~s}$, annealing at $54.5^{\circ} \mathrm{C}$ for $5 \mathrm{~s}$ and extension at $72{ }^{\circ} \mathrm{C}$ for $20 \mathrm{~s}$, and a final extension step at $72{ }^{\circ} \mathrm{C}$ for $1 \mathrm{~min}$. A PCR-restriction fragment length polymorphism (PCR-RFLP) assay [41] was performed on the PCR product, using the restriction enzymes FspBi and SspI (Thermo Fischer Scientific; Vilnius, Lithuania).

Culex pipiens molestus mosquitoes, originating from a field population sampled in Gothenburg, Sweden [42] and reared in our in-house mosquito rearing facility, were used as positive controls in PCR as they are naturally infected with a $w$ Pip strain of Wolbachia (data not shown). These were also used for PCR optimization.

\section{Wolbachia detection}

Wolbachia detection was performed through PCR on $5 \mu \mathrm{l}$ of the mosquito homogenate, using the same Tissue Direct kit procedures as described above. Wolbachia primers 81F (5'-TGGTCCAATAAGTGATGA AGAAAC-3') and 691R (5'-AAAAATTAAACGCTA CTCCA-3'), designed for general detection of Wolbachia within supergroups A and B [43], were used at a final concentration of $0.5 \mu \mathrm{M}$ each. The thermocycler conditions for Wolbachia detection were as described above but with the annealing temperature set to $58^{\circ} \mathrm{C}$. A subset of samples was also tested with a confirmatory PCR to determine whether the detected wsp gene Wolbachia belonged to that of the $w$ Pip strain using $w$ Pipspecific primers wPF (5'-CGACGTTAGTGGTGC AACATTTA-3') and wPR (5'-AATAACGAGCACCAG CAAAGAGT-3') [44] with the same PCR conditions as described previously but with the annealing temperature set to $56{ }^{\circ} \mathrm{C}$. For primer optimization, DNA integrity was controlled by extraction of total DNA to make sure that a negative PCR result was not due to DNA degradation in the sample. DNA was extracted from 44 samples with the E.Z.N.A. ${ }^{\circledR}$ Tissue DNA Kit (Omega Bio-Tek, Inc., Norcross, GA, USA), and visual inspection of DNA integrity was done by gel electrophoresis. Extracted DNA and all PCR products were visualized on $1.8 \%$ agarose gel stained with GelRed ${ }^{\circledR}$ Nucleic Acid Gel Stain (Biotium, Fremont, CA, USA) (Fig. 2). A subset of PCR products was purified with ExoSAPIT $^{\circledR}$ (Thermo Fischer Scientific; Vilnius, Lithuania) and sequenced through Sanger sequencing (Macrogen; 


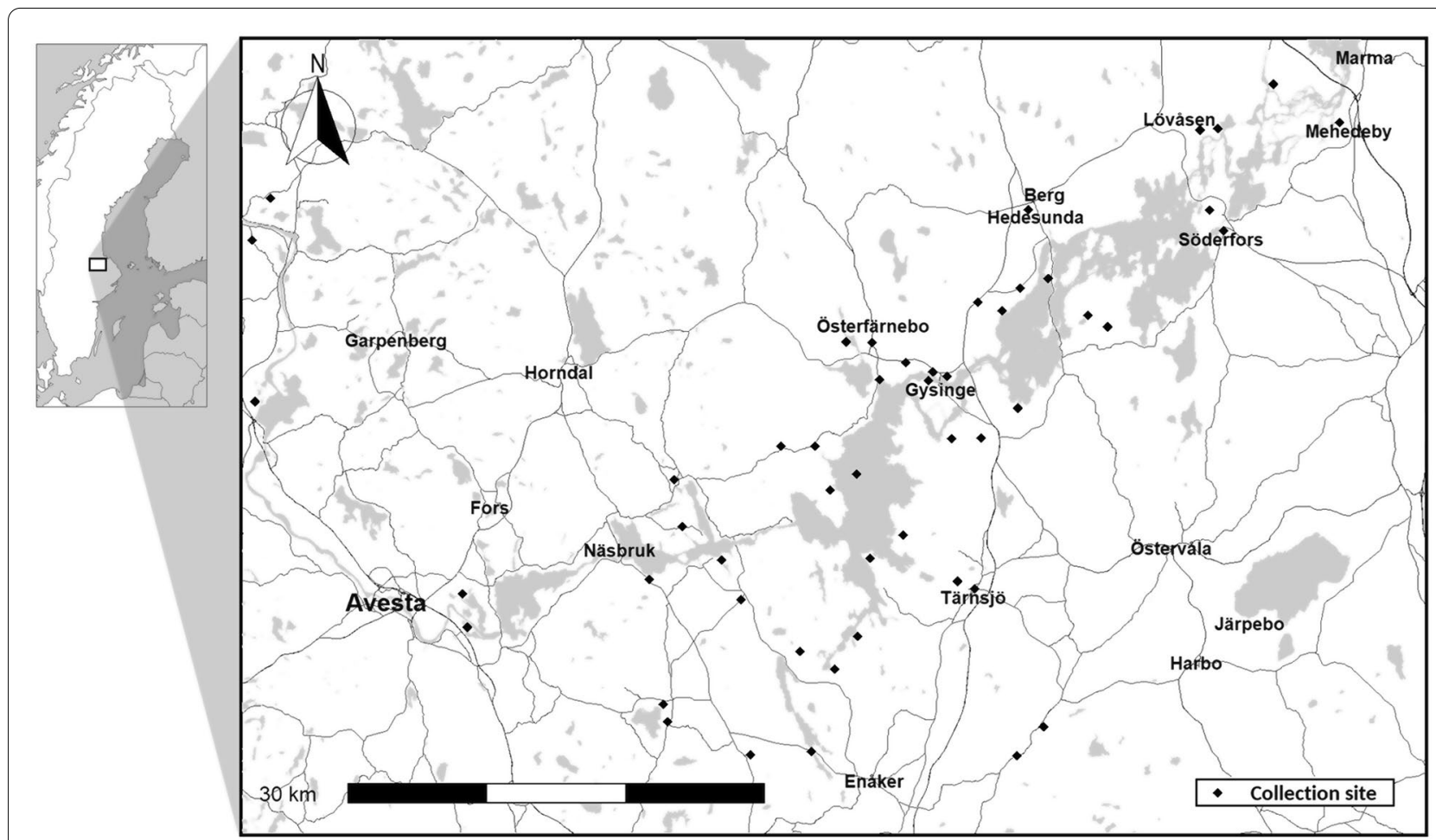

Fig. 1 Map showing the collection sites of Wolbachia-screened Culex mosquitoes. Collection sites are marked as black diamonds. Map data retrieved from ${ }^{\odot}$ OpenStreetMap contributors under the Open Database License

Amsterdam, The Netherlands) to validate the method and verify the results.

\section{Data analysis}

All records were kept and analysed in Microsoft Excel 2016 (Microsoft; Redmond, CA, USA). Confidence intervals for Wolbachia prevalence were calculated assuming binomial distribution using the Wilson score interval through RStudio (RStudio team, Boston, USA). $P$-values to determine statistical significance for differences in Wolbachia prevalence between years were calculated using Fisher's exact test with Bonferroni correction. Sequences of PCR fragments were analysed in the BioEdit sequence alignment editor version 7.2.5 [45].

\section{Results}

In total, 969 Culex mosquitoes (676 Cx. pipiens and 293 $C x$. torrentium) were identified to species and tested for Wolbachia (Fig. 2). Wolbachia was present in 96.5\% of the Cx. pipiens population (95\% CI 94.8-97.6\%) but could only be detected in two out of $293 \mathrm{Cx}$. torrentium individuals $(0.68 \%$ prevalence, $95 \%$ CI $0.19-2.45 \%)$ (Table 1). Three of the Cx. pipiens that carried Wolbachia from each year were tested with primers specific to the $w$ Pip variant of $w s p$, of which all 27 were found to carry a $w s p$ belonging to the $w$ Pip strain. In 2012, the prevalence of Wolbachia in Cx. pipiens was significantly lower than normal (Fisher's exact test: $P=0.00455$, OR: $0.389 \mathrm{CI}$ [0.198-0.778], Bonferroni-corrected $P=0.041$ ).

Two Cx. torrentium were found to carry Wolbachia. Sequencing of the amplicons showed that the two partial wsp sequences were only $90 \%$ identical to each other. The wsp sequence from one of the $C x$. torrentium individuals was very similar (>99.8\% identity) to the $w s p$ of Wolbachia from Cx. pipiens (GenBank: KT964224.1), but also to isolates from the winter moth (Operophtera brumata: GenBank: KY587652.1), cabbage moth (Mamestra brassicae; GenBank: AB094375.1), and Toya propinqua (GenBank: KM386826.1). The other Cx. torrentium carried a Wolbachia whose wsp gene was highly similar (> 99.6\% identity) to that of Wolbachia detected in several other insects, namely the spotted fritillary (Melitaea didyma; GenBank: MN322891.1), silverleaf whitefly (Bemisia tabaci; GenBank: AJ291379.1), azalea lace bug (Stephanitis pyrioides, GenBank: AB109622.1), Macrolophus pygmaeus (GenBank: FJ374283.1), and Amaurosoma flavipes (GenBank: JN601166.1), all of which carry Wolbachia from supergroup B. The sequencing results were confirmed by PCR using the $w$ Pip-specific wsp primers. This PCR amplified a correct fragment from 
only one of the two Wolbachia-positive Cx. torrentium (Fig. 3).

\section{Discussion}

We found that Wolbachia was highly prevalent in $C x$. pipiens collected around the River Dalälven floodplains, while it was nearly absent from Cx. torrentium. This is in line with previous European studies investigating large samples of $C x$. pipiens, with reported Wolbachia prevalence of $91 \%$ in western Russia [35], 95\% in central

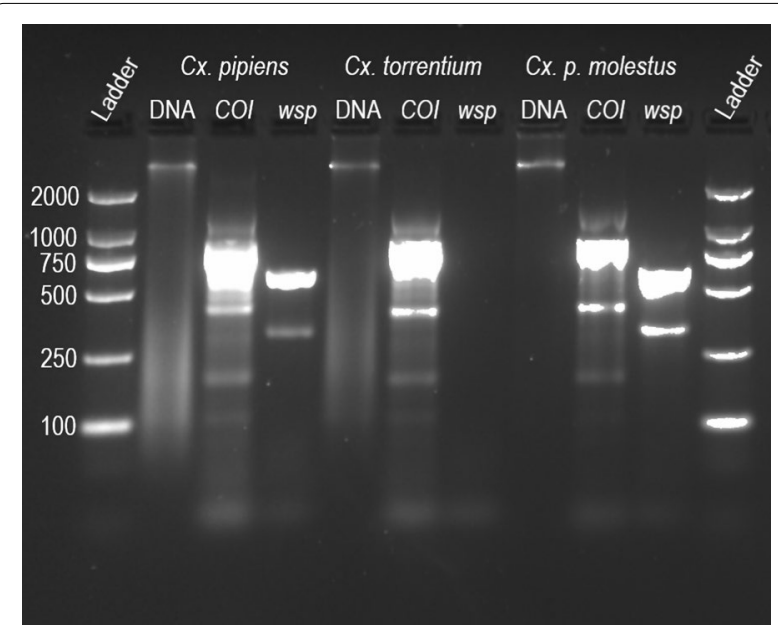

Fig. 2 Representative agarose gel of extracted DNA and amplified PCR products. The extracted DNA (lanes 2, 5, and 7), amplified cytochrome oxidase subunit I (COI) gene (lanes 3, 6, and 9), and amplified wsp gene (lanes 4, 7, and 10) are shown for an individual of each of the species $C$ x. pipiens, $C$. torrentium, and $C$ x. pipiens molestus, respectively
Russia, $81 \%$ in Belarus [36], and 93\% in Germany [37]. Raharimalala et al. [38] detected Wolbachia in nine out of nine tested adult $C x$. pipiens and 26 out of 48 larvae collected in Belgium, which also supports the generally high prevalence of Wolbachia in this species. Interestingly, the different populations studied by Khrabrova et al. [36] had varying levels of Wolbachia prevalence, some with as few as $34.5 \%$ of individuals carrying the endosymbiont. Wolbachia is reported to approach fixation in most $C x$. pipiens populations worldwide [46, 47], but this does not seem to hold true for all European populations.

Only Ricci et al. [48] have, to our knowledge, previously found Wolbachia in Cx. torrentium, after testing only two individuals collected in Italy. Raharimalala et al. [38], Leggewie et al. [37], Vinogradova et al. [35], and Khrabrova et al. [36] detected no Wolbachia in Cx. torrentium despite having tested 42 Belgian, 188 German, 321 Russian, and 853 Eastern European individuals, respectively. Our study, as well as the study by Ricci et al. [47], tested adult mosquitoes, while the four that failed to detect Wolbachia in Cx. torrentium tested field-collected larvae and pupae. Wolbachia is usually inherited and should thus be present in all life stages of the mosquito; however, life stage is still potentially an important consideration when screening for Wolbachia, both to avoid analysing siblings and to detect potential horizontal transmission.

Due to the low prevalence of Wolbachia in Cx. torrentium, we hypothesize that the two positive individuals or their recent ancestors acquired the infection horizontally. Transmission could potentially have occurred by feeding on the same plants as other arthropods $[49,50]$ or through arthropod parasites, such as through mites sometimes feeding on mosquitoes [51,52]. Despite wsp

Table 1 Results of the screening of Cx. pipiens and Cx. torrentium for Wolbachia

\begin{tabular}{|c|c|c|c|c|c|c|c|}
\hline \multirow[t]{3}{*}{ Year } & \multicolumn{6}{|l|}{ Species } & \multirow[t]{3}{*}{ Total tested } \\
\hline & \multicolumn{3}{|c|}{ Culexpipiens } & \multicolumn{3}{|c|}{ Culex torrentium } & \\
\hline & Tested & Positive & $\%$ positive & Tested & Positive & $\%$ positive & \\
\hline 2010 & 93 & 92 & 98.9 & 49 & 0 & 0 & 142 \\
\hline 2011 & 21 & 21 & 100 & 30 & 0 & 0 & 51 \\
\hline 2012 & 208 & 190 & 91.3 & 71 & 0 & 0 & 279 \\
\hline 2013 & 62 & 60 & 96.8 & 52 & 0 & 0 & 114 \\
\hline 2014 & 6 & 5 & 83.3 & 2 & 0 & 0 & 8 \\
\hline 2015 & 76 & 75 & 98.7 & 39 & 2 & 5.2 & 115 \\
\hline 2016 & 30 & 30 & 100 & 30 & 0 & 0 & 60 \\
\hline 2017 & 53 & 53 & 100 & 10 & 0 & 0 & 63 \\
\hline 2018 & 127 & 126 & 99.2 & 10 & 0 & 0 & 137 \\
\hline Total & 676 & 652 & 96.5 & 293 & 2 & 0.7 & 969 \\
\hline
\end{tabular}

The mosquitoes were collected in central Sweden between 2010 and 2018. The prevalence of Wolbachia in Cx. pipiens differed significantly in year 2012 from the 9-year average (Fisher's exact test: $P=0.00455$, OR: $0.389 \mathrm{CI}[0.198-0.778]$, Bonferroni-corrected $P=0.041$ ). The differences for all other years are non-significant 
being a poor marker of Wolbachia strain due to its tendency to recombine [53], the lineage of the Cx. torrentium whose wsp gene matched that of the $w$ Pip strain could have acquired its infection from a $C x$. pipiens through their shared habitat and ecological niche. Alternative sources are also possible, since a highly similar wsp sequence has also been found in other Palearctic insects. Further studies on the mechanisms for horizontal Wolbachia transmission involving mosquitoes are needed to fully explain the occasional spread of Wolbachia to $C x$. torrentium.

The restriction of SINV outbreaks to Northern Europe has been suggested to be connected to the relatively higher abundance of the competent vector species $C x$. torrentium in SINV-endemic regions [31, 32]. Under laboratory conditions, $C x$. torrentium is significantly more susceptible to SINV infection than Cx. pipiens [34, 54]. The presence of Wolbachia in Cx. pipiens may contribute to its lower susceptibility to SINV. Such reduction in vector competence is often seen when transferring a novel Wolbachia strain into a mosquito species that is naturally Wolbachia-free or naturally carries a different strain $[11,55-58]$, but the impact of a naturally occurring Wolbachia infection (i.e., native infection) is not as clear, with reports of both reduced vector competence $[13,14,59]$ and no observed effect [60-63]. No vector competence studies have been done on the role of $\mathrm{Wol}$ bachia in alphavirus transmission in Culex mosquitoes. With relatively few data to extrapolate from, empirical

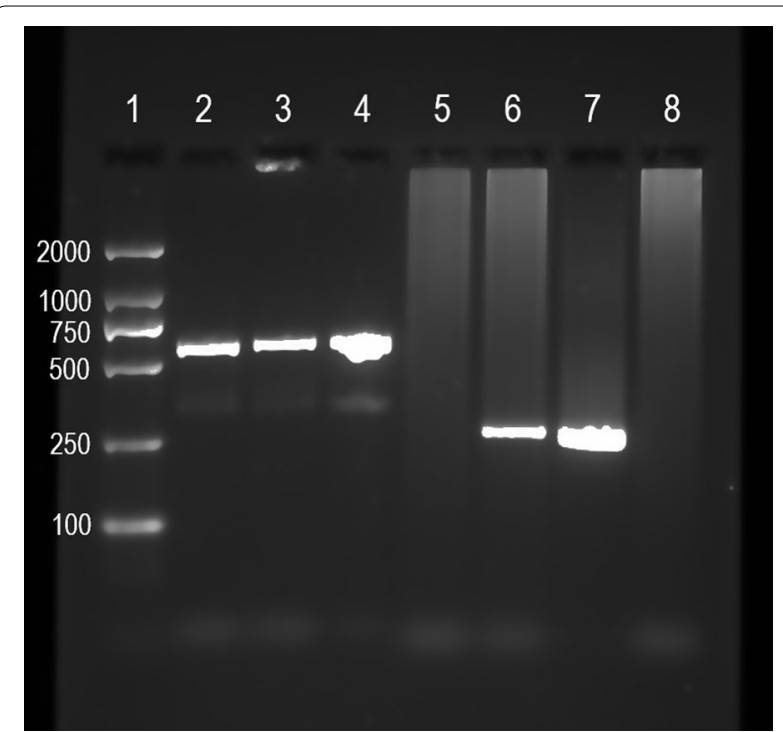

Fig. 3 Gel showing amplification with general wsp primers ( $C x$. torrentium in lanes 2-3, Cx. pipiens molestus in lane 4), and with specific wPip primers (Cx. torrentium in lanes 5-6, Cx. pipiens molestus in lane 7). Lane 1 shows a size ladder and lane 8 shows a combined non-template control for general and specific wsp amplification investigation is needed to evaluate the impact of $\mathrm{Wol}$ bachia on the SINV transmission cycle.

\section{Conclusions}

Our study, performed in a SINV-endemic region of Sweden, confirmed previously reported general patterns of Wolbachia infection in Culex mosquitoes, with most $C x$. pipiens and very few $C x$. torrentium carrying the endosymbiont, which potentially has implications for their differences in vector competence. Our findings, paired with the specific conditions under which SINV is transmitted in Sweden, prompt more research into Wolbachia's role in the SINV transmission cycle as well as the horizontal routes of Wolbachia transmission among mosquitoes.

\section{Abbreviations}

CDC: Centers for Disease Control and Prevention; CHIKV: Chikungunya virus; COI: Cytochrome oxidase subunit I; Cx.: Culex; JEV: Japanese encephalitis virus; PBS: Phosphate buffered saline; PCR-RFLP: Polymerase chain reaction-restriction fragment length polymorphism; SINV: Sindbis virus; WNV: West Nile virus.

\section{Acknowledgements}

The authors are grateful to Jan O. Lundström for providing mosquito material, and for the financial support received from the funders described above.

\section{Authors' contributions}

JCH conceptualized, supervised, and administered the project, acquired mosquito material and funding, and reviewed and contributed to the manuscript. $\mathrm{AB}$ conducted DNA extraction, Wolbachia screening and species verification, and wrote the manuscript. Both authors have read and approved the final manuscript.

\section{Funding}

Open access funding provided by Uppsala University. The research was funded by the Swedish Society for Medical Research, the Carl Trygger Foundation, and the European Union's Horizon 2020 research and innovation programme under Grant No. 874735 (VEO). None of the funding bodies had any role in the design of the study or collection, analysis, and interpretation of data, or in drafting of the manuscript.

Availability of data and materials

For amplicon sequences of the Wolbachia detected in $C x$. torrentium and $C X$. pipiens, the data sets generated and/or analysed during the current study are available in the GenBank repository, accession numbers MW622245MW622247. All other data sets used and/or analysed during the current study are available from the corresponding author on reasonable request.

\section{Declarations}

Ethics approval and consent to participate Not applicable.

\section{Consent for publication \\ Not applicable.}

\section{Competing interests}

The authors declare that they have no competing interests.

Received: 25 February 2021 Accepted: 7 August 2021

Published online: 26 August 2021 


\section{References}

1. Ramirez JL, Souza-Neto J, Cosme RT, Rovira J, Ortiz A, Pascale JM, et al. Reciprocal tripartite interactions between the Aedes aegypti midgut microbiota, innate immune system and dengue virus influences vector competence. PLoS Negl Trop Dis. 2012;6:e1561.

2. Sim S, Jupatanakul N, Dimopoulos G. Mosquito immunity against arboviruses. Viruses. 2014:6:4479-504.

3. Zouache K, Fontaine A, Vega-Rua A, Mousson L, Thiberge J-M, LourencoDe-Oliveira $R$, et al. Three-way interactions between mosquito population, viral strain and temperature underlying chikungunya virus transmission potential. Proc R Soc B. 2014;281:20141078.

4. Ciota AT, Keyel AC. The role of temperature in transmission of zoonotic arboviruses. Viruses. 2019;11:1013.

5. Zug R, Hammerstein P. Still a host of hosts for Wolbachia: analysis of recent data suggests that $40 \%$ of terrestrial arthropod species are infected. PLoS ONE. 2012;7:e38544.

6. Landmann F. The Wolbachia endosymbionts. Microbiol Spectr. 2019. https://doi.org/10.1128/microbiolspec.BAl-0018-2019.

7. Werren JH, Baldo L, Clark ME. Wolbachia: master manipulators of invertebrate biology. Nat Rev Microbiol. 2008:6:741-51.

8. Hoffmann AA. Incompatible mosquitoes. Nature. 2005;436:189.

9. Sinkins SP, Walker T, Lynd AR, Steven AR, Makepeace BL, Godfray JHC, et al. Wolbachia variability and host effects on crossing type in Culex mosquitoes. Nature. 2005;436:257-60.

10. Bonneau M, Atyame C, Beji M, Justy F, Cohen-Gonsaud M, Sicard M, et al. Culex pipiens crossing type diversity is governed by an amplified and polymorphic operon of Wolbachia. Nat Commun. 2018;9:319.

11. Walker T, Johnson PH, Moreira LA, Iturbe-Ormaetxe I, Frentiu FD, McMeniman CJ, et al. The wMel Wolbachia strain blocks dengue and invades caged Aedes aegypti populations. Nature. 2011;476:450-3.

12. Hoffmann AA, Montgomery BL, Popovici J, Iturbe-Ormaetxe I, Johnson $\mathrm{PH}$, Muzzi F, et al. Successful establishment of Wolbachia in Aedes populations to suppress dengue transmission. Nature. 2011;476:454-7.

13. Tsai C-H, Chen T-H, Lin C, Shu P-Y, Su C-L, Teng H-J. The impact of temperature and Wolbachia infection on vector competence of potential dengue vectors Aedes aegypti and Aedes albopictus in the transmission of dengue virus serotype 1 in southern Taiwan. Parasites Vectors. 2017:10(1):551.

14. Glaser RL, Meola MA. The native Wolbachia endosymbionts of Drosophila melanogaster and Culex quinquefasciatus increase host resistance to West Nile virus infection. PLoS ONE. 2010;5:e11977.

15. van den Hurk AF, Ritchie SA, Mackenzie JS. Ecology and geographical expansion of Japanese encephalitis virus. Annu Rev Entomol. 2009:54:17-35.

16. Reuben R, Tewari SC, Hiriyan J, Akiyama J. Illustrated keys to species of Culex (Culex) associated with Japanese encephalitis in Southeast Asia (Diptera: Culicidae). Mosq Syst. 1994:26:75-96.

17. Fros JJ, Miesen P, Vogels CB, Gaibani P, Sambri V, Martina BE, et al. Comparative Usutu and West Nile virus transmission potential by local Culex pipiens mosquitoes in north-western Europe. One Health. 2015;1:31-6.

18. Fortuna C, Remoli ME, Di Luca M, Severini F, Toma L, Benedetti E, et al. Experimental studies on comparison of the vector competence of four Italian Culex pipiens populations for West Nile virus. Parasites Vectors. 2015;8:463.

19. Francy DB, Jaenson TG, Lundström JO, Schildt EB, Espmark A, Henriksson $B$, et al. Ecologic studies of mosquitoes and birds as hosts of Ockelbo virus in Sweden and isolation of Inkoo and Batai viruses from mosquitoes. Am J Trop Med Hyg. 1989;41:355-63.

20. Jöst H, Bialonski A, Storch V, Günther S, Becker N, Schmidt-Chanasit J. Isolation and phylogenetic analysis of Sindbis viruses from mosquitoes in Germany. J Clin Microbiol. 2010;48:1900-3.

21. Leggewie M, Badusche M, Rudolf M, Jansen S, Börstler J, Krumkamp R, et al. Culex pipiens and Culex torrentium populations from Central Europe are susceptible to West Nile virus infection. One Health. 2016:2:88-94.

22. Lundström JO, Hesson JC, Schäfer ML, Östman Ö, Semmler T, Bekaert M, et al. Sindbis virus polyarthritis outbreak signalled by virus prevalence in the mosquito vectors. PLoS Negl Trop Dis. 2019;13:e0007702.

23. Adouchief S, Smura T, Sane J, Vapalahti O, Kurkela S. Sindbis virus as a human pathogen-epidemiology, clinical picture and pathogenesis. Rev Med Vir. 2016;26:221-41
24. Storm N, Weyer J, Markotter W, Kemp A, Leman PA, Dermaux-Msimang V, et al. Human cases of Sindbis fever in South Africa, 2006-2010. Epidemiol Infect. 2013;142:234-8.

25. Jupp PG, Blackburn NK, Thompson DL, Meenehan GM. Sindbis and West Nile virus infections in the Witwatersrand-Pretoria region. S Afr Med J. 1986;70:218-20

26. Brummer-Korvenkontio M, Vapalahti O, Kuusisto P, Saikku P, Manni T, Koskela P, et al. Epidemiology of Sindbis virus infections in Finland 1981-96: possible factors explaining a peculiar disease pattern. Epidemiol Infect. 2002;129:335-45

27. Sane J, Guedes S, Kurkela S, Lyytikäinen O, Vapalahti O. Epidemiological analysis of mosquito-borne Pogosta disease in Finland, 2009. Euro Surveill. 2010;15:19462.

28. Lundström JO, Vene S, Espmark Å, Engvall M, Niklasson B. Geographical and temporal distribution of Ockelbo disease in Sweden. Epidemiol Infect. 1991;106:567-74.

29. Bergqvist J, Forsman O, Larsson P, Näslund J, Lilja T, Engdahl C, et al. Detection and isolation of Sindbis virus from mosquitoes captured during an outbreak in Sweden, 2013. Vector Borne Zoonotic Dis. 2015;15:133-40.

30. AhIm C, Eliasson M, Vapalahti O, Evander M. Seroprevalence of Sindbis virus and associated risk factors in northern Sweden. Epidemiol Infect. 2013;142:1559-65.

31. Hesson JC, Östman Ö, Schäfer M, Lundström JO. Geographic distribution and relative abundance of the sibling vector species Culex torrentium and Culex pipiens in Sweden. Vector Borne Zoonotic Dis. 2011;11:1383-9.

32. Hesson JC, Rettich F, Merdić E, Vignjević G, Östman Ö, Schäfer M, et al. The arbovirus vector Culex torrentium is more prevalent than Culexpipiens in northern and central Europe. Med Vet Entomol. 2013;28:179-86.

33. Hesson JC, Verner-Carlsson J, Larsson A, Ahmed R, Lundkvist A, Lundström JO. Culex torrentium mosquito role as major enzootic vector defined by rate of Sindbis virus infection, Sweden, 2009. Emerg Infect Dis. 2015;21:875-8.

34. Lundström JO, Niklasson B, Francy DB. Swedish Culex torrentium and CX. pipiens (Diptera: Culicidae) as experimental vectors of Ockelbo virus. J Med Entomol. 1990;27:561-3.

35. Vinogradova EB, Shaikevich EV, Ivanitsky AV. A study of the distribution of Culex pipiens complex (Insecta: Diptera: Culicidae) mosquitoes in the European part of Russia by molecular methods of identification. Comp Cytogenet. 2007;1:129-38.

36. Khrabrova NV, Bukhanskaya ED, Sibataev AK, Volkova TV. The distribution of strains of endosymbiotic bacteria Wolbachia pipientis in natura populations of Culex pipiens mosquitoes (Diptera: Culicidae). Eur Mosq Bull. 2009;27:18-22.

37. Leggewie M, Krumkamp R, Badusche M, Heitmann A, Jansen S, SchmidtChanasit J, et al. Culex torrentium mosquitoes from Germany are negative for Wolbachia. Med Vet Entomol. 2017;32:115-20.

38. Raharimalala FN, Boukraa S, Bawin T, Boyer S, Francis F. Molecular detection of six (endo-) symbiotic bacteria in Belgian mosquitoes: first step towards the selection of appropriate paratransgenesis candidates. Parasitol Res. 2015:115:1391-9.

39. Schäfer M, Wahlqvist $P$, Lundström JO. Stickmyggmängder vid nedre Dalälven [Amounts of mosquitoes at lower Dalälven]. Biologisk Myggkontroll inom NEDAB. 2018. http://www.utslappshandel.se/upload/stod-i-miljoarbet et/remisser-och-yttranden/remisser-2018/ansokan-mygg-nedre-dalalven/ bilaga5-stickmyggmangder-vid-nedre-dalalven.pdf. Accessed 22 Oct 2020.

40. Becker N, Petric D, Zgomba M, Boase C, Dahl C, Lane J, et al. Mosquitoes and their control. 2nd ed. Heidelberg: Springer; 2010.

41. Hesson JC, Lundström JO, Halvarsson P, Erixon P, Collado A. A sensitive and reliable restriction enzyme assay to distinguish between the mosquitoes Culex torrentium and Culex pipiens. Med Vet Entomol. 2010;24:142-9.

42. Hesson JC, Schäfer M, Lundström JO. First report on human-biting Culex pipiens in Sweden. Parasit Vectors. 2016;9:632.

43. Zhou W, Rousset F, O'Neill S. Phylogeny and PCR-based classification of Wolbachia strains using wsp gene sequences. Proc R Soc Lond B. 1998:265:509-15.

44. Calvitti M, Moretti R, Skidmore AR, Dobson SL. Wolbachia strain wPip yields a pattern of cytoplasmic incompatibility enhancing a Wolbachia-based suppression strategy against the disease vector Aedes albopictus. Parasites Vectors. 2012;5:254 
45. Hall TA. BioEdit: a user-friendly biological sequence alignment editor and analysis program for Windows 95/98/NT. Nucleic Acids Symp Ser. 1999:41:95-8.

46. Duron O, Lagnel J, Raymond M, Bourtzis K, Fort P, Weill M. Transposable element polymorphism of Wolbachia in the mosquito Culexpipiens: evidence of genetic diversity, superinfection and recombination. Mol Ecol. 2005;14:1561-73.

47. Dumas E, Atyame CM, Milesi P, Fonseca DM, Shaikevich EV, Unal S, et al. Population structure of Wolbachia and cytoplasmic introgression in a complex of mosquito species. BMC Evol Biol. 2013;13:181.

48. Ricci I, Cancrini G, Gabrielli S, D'amelio S, Favia G. Searching for Wolbachia (Rickettsiales: Rickettsiaceae) in mosquitoes (Diptera: Culicidae): large polymerase chain reaction survey and new identifications. J Med Entomol. 2002:39:562-7.

49. Li S-J, Ahmed MZ, Lv N, Shi P-Q, Wang X-M, Huang J-L, et al. Plantmediated horizontal transmission of Wolbachia between whiteflies. ISME J. 2016;11:1019-28.

50. Sintupachee S, Milne JR, Poonchaisri S, Baimai V, Kittayapong P. Closely related Wolbachia strains within the pumpkin arthropod community and the potential for horizontal transmission via the plant. Microb Ecol. 2006;51:294-301.

51. Cook JM, Butcher RDJ. The transmission and effects of Wolbachia bacteria in parasitoids. Res Popul Ecol. 1999;41:15-28.

52. Brown AN, Lloyd VK. Evidence for horizontal transfer of Wolbachia by a Drosophila mite. Exp Appl Acarol. 2015;66:301-11.

53. Baldo L, Lo N, Werren JH. Mosaic nature of the Wolbachia surface protein. JB. 2005;187:5406-18.

54. Lwande OW, Näslund J, Lundmark E, Ahlm K, Ahlm C, Bucht G, et al. Experimental infection and transmission competence of Sindbis virus in Culex torrentium and Culex pipiens mosquitoes from northern Sweden. Vector Borne Zoonotic Dis. 2019;19:128-33.

55. Moreira LA, Iturbe-Ormaetxe I, Jeffery JA, Lu G, Pyke AT, Hedges LM, et al. A Wolbachia symbiont in Aedes aegypti limits infection with dengue, chikungunya, and Plasmodium. Cell. 2009;139:1268-78.
56. Blagrove MSC, Arias-Goeta C, Di Genua C, Failloux A-B, Sinkins SP. A Wo/bachia wMel transinfection in Aedes albopictus is not detrimental to host fitness and inhibits chikungunya virus. PLoS Negl Trop Dis. 2013;7:e2152.

57. Ant TH, Herd CS, Geoghegan V, Hoffmann AA, Sinkins SP. The Wolbachia strain wAu provides highly efficient virus transmission blocking in Aedes aegypti. PLOS Pathog. 2018;14:e1006815.

58. Caragata EP, Rocha MN, Pereira TN, Mansur SB, Dutra HLC, Moreira LA. Pathogen blocking in Wolbachia-infected Aedes aegypti is not affected by Zika and dengue virus co-infection. PLoS Negl Trop Dis. 2019;13:e0007443.

59. Mousson L, Zouache K, Arias-Goeta C, Raquin V, Mavingui P, Failloux A-B. The native Wolbachia symbionts limit transmission of dengue virus in Aedes albopictus. PLoS Negl Trop Dis. 2012;6:e1989.

60. Mousson L, Martin E, Zouache K, Madec Y, Mavingui P, Failloux AB. Wolbachia modulates chikungunya replication in Aedes albopictus. Mol Ecol. 2010;19:1953-64.

61. Micieli MV, Glaser RL. Somatic Wolbachia (Rickettsiales: Rickettsiaceae) levels in Culex quinquefasciatus and Culex pipiens (Diptera: Culicidae) and resistance to West Nile virus infection. J Med Entom. 2014;51:189-99.

62. Ahmad NA, Vythilingam I, Lim YAL, Zabari NZAM, Lee HL. Detection of Wolbachia in Aedes albopictus and their effects on chikungunya virus. Am J Trop Med Hyg. 2016;96:148-56.

63. Joanne S, Vythilingam I, Teoh B-T, Leong C-S, Tan K-K, Wong M-L, et al. Vector competence of Malaysian Aedes albopictus with and without Wolbachia to four dengue virus serotypes. Trop Med Int Health. 2017;22:1154-65.

\section{Publisher's Note}

Springer Nature remains neutral with regard to jurisdictional claims in published maps and institutional affiliations.
Ready to submit your research? Choose BMC and benefit from:

- fast, convenient online submission

- thorough peer review by experienced researchers in your field

- rapid publication on acceptance

- support for research data, including large and complex data types

- gold Open Access which fosters wider collaboration and increased citations

- maximum visibility for your research: over 100M website views per year

At BMC, research is always in progress.

Learn more biomedcentral.com/submissions 